\title{
LITHIUM COBALT SPINEL OXIDE: A STRUCTURAL AND ELECTROCHEMICAL STUDY
}

\author{
ERIKA MEZA, DANIELA ALBURQUENQUE, JUAN ORTIZ, JUAN LUIS GAUTIER* \\ LEFQS, Departamento de Química de los Materiales, Facultad de Química y Biología, \\ Universidad de Santiago de Chile, Ave. L.B. O'Higgins 3363, Santiago, Chile. \\ (Received: 2 October 2007 - Accepted: 8 April 2008)
}

\begin{abstract}
Lithium cobaltite, $\mathrm{LiCo}_{2} \mathrm{O}_{4}$, prepared by thermal decomposition of nitrates salts was synthesized at $400{ }^{\circ} \mathrm{C}$. X-ray Rietveld refinement showed the presence of two phases: a cubic spinel $\left(\mathrm{Co}_{3} \mathrm{O}_{4}\right)$ and other corresponding to spinel-like, which could not be classified as $\mathrm{LiCo}_{2} \mathrm{O}_{4}$ or $\mathrm{LiCoO}_{2}$ since both crystallized in Fd3m S.G.

Electrochemical determinations (charge-discharge curves and impedance spectroscopy measurements) showed that $\mathrm{Li}^{+}$ion is inserted into the spinel lattice, with $\mathrm{D}=810^{-16} \mathrm{~cm} \mathrm{~s}^{-1}$ at $2.00-2.25 \mathrm{~V}$ potential range whereas lithium extraction occurred at 3.2-3.8 $\mathrm{V}$ potential range.
\end{abstract}

Keywords: lithium cobalt oxide, lithium intercalation materials, lithium ion batteries, spinel, mixed oxides.

\section{INTRODUCTION}

Lithium transition double metal oxides $\mathrm{LiMO}_{2}(\mathrm{M}=\mathrm{Co}, \mathrm{Mn}, \mathrm{Ni})$ with layered or spinel structure $\left(\mathrm{LiMn}_{2} \mathrm{O}_{4}\right)$ are efficient cathodes for lithium rechargeable batteries. Most of the commercial $\mathrm{Li}$-ion cells currently use layered $\mathrm{LiCoO}_{2}$ material because of their high voltage, high energy density $(\sim 500 \mathrm{Wh} / \mathrm{Kg})$ and high recycling ability. It is well known that $\mathrm{LiCoO}_{2}$ can crvstallize in three different structural phases: hexagonal close packing with $R 3 m$ space group, cubic close-packed arrangement with $\mathrm{Fm} 3 \mathrm{~m}$ group and spinel with $\mathrm{Fd}^{-} \mathrm{m}$ or $F d 3 m$ group. Hexagonal and spinel phases exhibit electrochemical activity. However, only $50 \%$ of the theoretical capacity of $\mathrm{LiCoO}_{2}$ can be practically utilized $(140 \mathrm{Ah} / \mathrm{Kg})$, which corresponds to a reversible lithium extraction range of $1 \geq 1-\mathrm{x} \geq 0.5$ in $\mathrm{Li}_{1-x} \mathrm{CoO}_{2}$. In order to generate this compound, several methods of synthesis have been investigated: co-precipitation ${ }^{1,2}$, solgel $^{3}$, hydrothermal ${ }^{4,5}$, ion exchange reactions ${ }^{6}$, reflux reactions ${ }^{5}$, hydrothermalelectrochemical ${ }^{7}$ and electrochemical reflux ${ }^{8}$.

The performance of $\mathrm{LiMO}_{2}$ (with $\mathrm{M}=\mathrm{Co}, \mathrm{Mn}$ ) electrodes decreases during the electrochemical cycling by the formation of less active spinel-like than hexagonal phases such as $\mathrm{Li}_{0.5} \mathrm{CoO}_{2}{ }^{9}$ or $\mathrm{Li}_{1-\mathrm{x}} \mathrm{MnO}_{2}{ }^{10}$. $\mathrm{A} \mathrm{Li}_{0.5} \mathrm{CoO}_{2}$ spinellike phase was detected for the first time by Gummow et al., who obtained it by delithiation of low temperature oxide, LT- $\mathrm{LiCoO}_{2}{ }^{11}$. A spinel phase showing the $\mathrm{Fd} 3 \mathrm{~m}$ space group was prepared from the rhombohedral layered oxide $\mathrm{Li}_{0.5} \mathrm{CoO}_{2}$ by heating at $200^{\circ} \mathrm{C}^{12}$. The $\mathrm{Li}_{0.5} \mathrm{CoO}_{2}$ oxide was synthesized previously by chemical lithium extraction from layered LT- $\mathrm{LiCoO}_{2}$ using $\mathrm{Na}_{2} \mathrm{~S}_{2} \mathrm{O}_{8}$ as the oxidizing agent. Transformation of the layered $\mathrm{Li}_{0} \mathrm{CoO}_{2}$ into the ideal spinel phase $(\mathrm{Li})_{8 \mathrm{a}}\left[\mathrm{Co}_{2}\right]_{16 \mathrm{~d}} \mathrm{O}_{4}$ requires the migration of $25 \%$ of the Co ions from the Co planes ( $3 \mathrm{~b}$ sites) into the lithium planes (3a sites) of the rhombohedral layer structure. However, the formation of the ideal spinel structure should be difficult considering the large $\mathrm{Co}^{3+}$ octahedral site stabilization energy; although theoretical calculations indicate that the formation of the low energy spinel is feasible ${ }^{13}$. Recently, non stoichiometric compounds of $\mathrm{Li}_{1-x} \mathrm{Co}_{2} \mathrm{O}_{4-\delta}(\mathrm{x}=0,0.4$, 0.56 and $\delta=0.13,0.52,0.64$ respectively) composition were synthesized by extracting lithium from $\mathrm{LT}-\mathrm{LiCoO}_{2}{ }^{14}$. All samples were indexed on the basis of the spinel structure within the space group $F d 3 m$ exhibiting intensities for the 111 index much higher than for the 311 index (whereas in other spinels with the same S.G. 311 is the main plane). The atomic distribution proposed for LT- $\mathrm{LiCoO}_{2}$ was $\left\{\mathrm{Li}_{2}\right\}_{16 \mathrm{c}}\left[\mathrm{Co}_{2}\right]_{160} \mathrm{O}_{4.03}$ (or $\mathrm{LiCoO}_{2.02}$ in the layered formalism), where $\mathrm{Co}$ would be in +3.03 oxidation state. The electrochemical extraction of lithium ions (equivalent to charged electrode) from $\mathrm{Li}_{1-\mathrm{C}} \mathrm{Co}_{2} \mathrm{O}_{4}$ is limited to $\mathrm{x}=0.6$ for the spinel prepared from $\mathrm{LT}-\mathrm{LiCoO}$, whereas the lithium could be completely extracted from the high temperature layered oxide, $\mathrm{HT}-\mathrm{LiCoO}_{2}{ }^{12}$.

Impossibility to prepare $\mathrm{LiCo}_{2} \mathrm{O}_{4}$ with normal spinel structure using classical methods has been communicated in the literature ${ }^{12}$. The aim of this work was the direct synthesis of this oxide showing ideal cubic spinel $F d 3 m$ space group using the thermal decomposition of nitrates (TDN) method. X-ray diffraction was used to obtain the atomic distribution considering the octahedral and tetrahedral spinel sites. The electrochemical cathode behavior and lithium diffusion into the electrodes were also studied.

\section{EXPERIMENTAL}

Lithium-cobalt oxides were prepared by the TDN method. LiNO (Merck p.a. ref. 12230) and $\mathrm{Co}\left(\mathrm{NO}_{3}\right)_{2} \times 6 \mathrm{H}_{2} \mathrm{O}$ (Fluka p.a. ref. 60833) were intimately mixed in $1: 2$ molar ratio and heated first at $120^{\circ} \mathrm{C}$ and then for $24 \mathrm{~h}$ at $200^{\circ} \mathrm{C}$ in the air. The powder obtained was ground at 300 mesh and finally calcined at $400^{\circ} \mathrm{C}$ in an oxygen atmosphere during $24 \mathrm{~h}$. X-ray diffraction (XRD), with a Siemens D5000 diffractometer using CoK radiation $(0.178897 \mathrm{~nm})$ was used to obtain structural information employing Bragg-Brentano scan geometry, a step size of $0.02^{\circ}, 4 \mathrm{~s}$ by step, and $5<2 \theta<90$. Electrochemical measurements were carried out using two electrode Swagelock ${ }^{\circledR}$ cells. The positive electrode (oxide pellet, 325 mesh) was separated from the negative lithium electrode $(99.9 \%$ Aldrich ref 26,598-5) by means of $0.3 \mathrm{~mm}$-thick porous glass paper disc soaked in the electrolyte, $1 \mathrm{M} \mathrm{LiBF}_{4}$ solution in ethylene carbonate (EC) and diethyl carbonate (DEC) $(1: 1 \mathrm{wt})$. The cathode ( $3 \mathrm{~mm}$ thick) was fabricated mixing the oxide with acetylene black (conducting additive) and polytetrafluoroethylene (PTFE) suspension (mechanical binding additive), in a weight ratio of 90:5:5. The lithium insertion (x) was achieved at $78 \mu \mathrm{A} \mathrm{cm}^{-2}$ (selected from previous experiments) using a home-made potentio-galvanostat device. The chemical diffusion coefficient (D) of the $\mathrm{Li}^{+}$ions in spinel samples was determined by electrochemical impedance spectroscopy (EIS) using a Voltalab PGZ 301 apparatus (Radiometer) and software Volta Master 4. The ac voltage amplitude was $200 \mathrm{mV}$ and the frequency range $0.01-10^{5} \mathrm{~Hz}$.

\section{RESULTS AND DISCUSSION}

\section{X-ray diffraction.}

Fig. 1 shows the X-ray diffractogram for the lithium-cobalt compound. A typical pattern corresponding to a cubic spinel structure is observed, where all the peaks were indexed according to the $F d 3 m$ space group ${ }^{15}$. The X-Ray

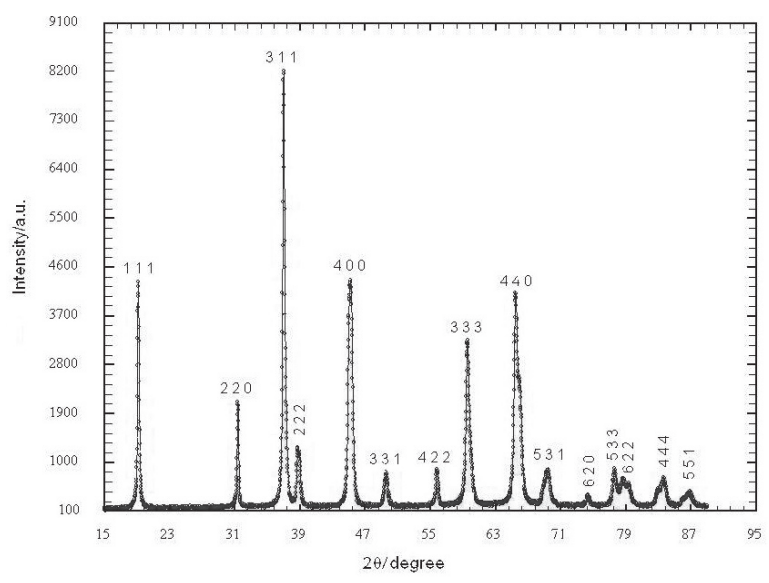

Figure 1. X-ray diffraction pattern of lithium cobaltite obtained by DTN. 
Diffraction is similar with those obtained by Gummow et al. ${ }^{11}$ for a lithium cobaltite prepared from carbonate salts. These authors considered a mixture formed by $\mathrm{Co}_{3} \mathrm{O}_{4}$ and a lithium-cobalt oxide known as "spinel like" derived from LT- $\mathrm{LiCoO}_{2}{ }^{12,16}$.

Three relevant differences are observed when the cubic spinel phase obtained here and the cubic spinel phase prepared by heating layered $\mathrm{Li}_{05} \mathrm{CoO}_{2}{ }^{6}$ are compared. First, in our case the principal plane is the (311) instead of (111) second, (220) and (422) reflections are present, and third, (018) and (110) reflections are absent. In an ideal cubic spinel structure, if $\mathrm{Li}$ and $\mathrm{Co}$ atoms are placed in tetrahedral $8 \mathrm{a}$ and octahedral $16 \mathrm{~d}$ sites, respectively, the (111) reflection should be the most intense (as in $\mathrm{Li}_{0.5} \mathrm{CoO}_{2}$ ). In turn, if $50 \%$ of $\mathrm{Li}$ atoms are placed simultaneously in octahedral and tetrahedral sites, the index of maximum intensity would be (311), as observed here. On the other hand, if Co atoms occupy only octahedral sites, the intensity of the indexes (111) and (400) should decrease similarly to the intensity of the (331) peak, which is clearly not the case (Fig. 1).

These evidences prompted us to carry out a Rietveld refinement analysis ${ }^{17}$. The best results were obtained assuming a mixture of $\mathrm{LiCo}_{2} \mathrm{O}_{4}$ (phase 1) and $\mathrm{Co}_{3} \mathrm{O}_{4}$ (phase 2), according to spinel model (S.G. $\mathrm{Fd}_{3} 3 \mathrm{~m}$ or $\left.\mathrm{Fd} 3 \mathrm{~m}\right)^{18}$. The atomic distributions $\left\{\mathrm{Li}_{0.5} \mathrm{Co}_{0.5}\right\}_{8 \mathrm{a}}\left[\mathrm{Li}_{0.25} \mathrm{Co}_{0.75}\right]_{16 \mathrm{~d}}\left(\mathrm{O}_{4}\right)_{32 \mathrm{e}}$ and $\left\{\mathrm{Co}_{8 \mathrm{a}}\left[\mathrm{Co}_{2}\right]_{16 \mathrm{~d}}\left(\mathrm{O}_{4}\right)_{32 \mathrm{e}}\right.$ were considered respectively. The observed and calculated XRD profiles are shown in Fig. 2.

The atom crystallographic position, $\mathrm{R}$-factors and a-lattice parameters are summarized in Table 1. The isotropic temperature factors (B) were obtained.

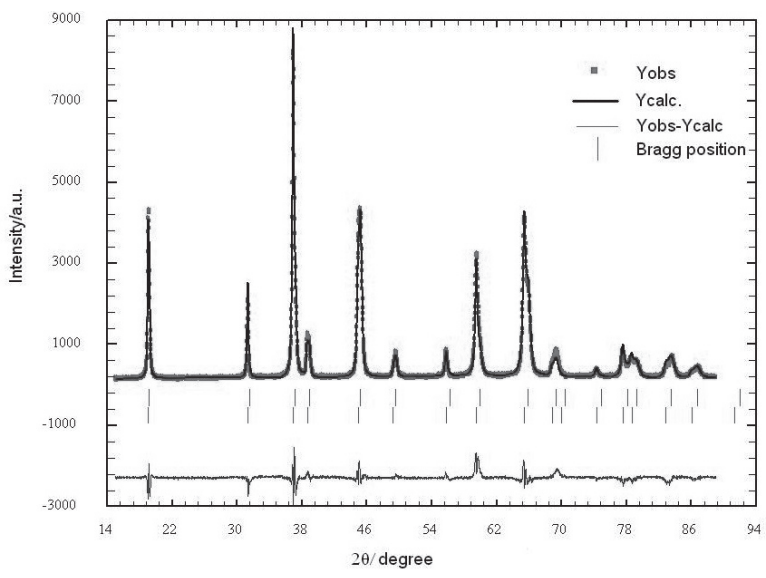

Figure 2. Observed and calculated XRD profiles for lithium cobaltite, refined in the Fd3m space group.

Table I. Crystallographic parameters of phase 1 and phase 2 Rietveld refinement.

$$
\mathrm{R}_{\mathrm{p}}=12.8 \% \quad \mathrm{R}_{\mathrm{wp}}=14.4 \% \quad \mathrm{R}_{\text {exp }}=6.48 \%
$$

Phase 1: $\mathrm{LiCo}_{2} \mathrm{O}_{4} \quad \mathrm{a}=0.8025 \mathrm{~nm} \quad \mathrm{R}_{\text {Bragg }}=5.42 \%$

\begin{tabular}{|l|ccc|c|c|}
\hline \multicolumn{1}{|c|}{ Atom } & $\mathrm{x}$ & $\mathrm{y}$ & $\mathrm{z}$ & $\begin{array}{c}\text { Chemical } \\
\text { Occupancy }\end{array}$ & B factor \\
\hline Li (8a) & 0.125 & 0.125 & 0.125 & 0.5 & 0.96 \\
\hline Co (8 a) & 0.125 & 0.125 & 0.125 & 0.5 & 0.96 \\
\hline Li (16d) & 0.500 & 0.500 & 0.500 & 0.25 & 0.96 \\
\hline Co (16d) & 0.500 & 0.500 & 0.500 & 0.75 & 0.96 \\
\hline O (32 e $)$ & 0.252 & 0.252 & 0.252 & 1.0 & 1.63 \\
\hline
\end{tabular}

\begin{tabular}{|l|rrr|c|c|l|}
\hline \multicolumn{1}{|c|}{ Phase 2: $\mathrm{Co}_{3} \mathrm{O}_{4}$} & $\mathrm{a}=0.8066 \mathrm{~nm}$ & $\mathrm{R}_{\text {Bragg }}=6.28 \%$ \\
\hline $\mathrm{Co}(8 \mathrm{a})$ & 0.125 & 0.125 & 0.125 & 1.00 & 0.96 \\
\hline $\mathrm{Co}(16 \mathrm{~d})$ & 0.500 & 0.500 & 0.500 & 1.00 & 0.96 \\
\hline $\mathrm{O}(32 \mathrm{e})$ & 0.262 & 0.262 & 0.262 & 1.00 & 1.63 \\
\hline
\end{tabular}

From Gummow et al. ${ }^{11}$. Rietveld results show the formation of a mixture of two phases, indistinguishable by XRD that crystallized in the same S.G. $(\mathrm{Fd} 3 \mathrm{~m})$. The Fullprof Program ${ }^{17}$ was used to calculate the mixture composition: $66 \%$ of phase $1\left(\mathrm{LiCo}_{2} \mathrm{O}_{4}\right.$ or LT- $\left.\mathrm{LiCoO}_{2}\right)$ and $34 \%$ of phase $2\left(\mathrm{Co}_{3} \mathrm{O}_{4}\right)$. Table 2 shows the positions of XRD lines. The presence of these phases can be accounted for since it has been shown that $\mathrm{LiCo}_{2} \mathrm{O}_{4}$ can disproportionate to $\mathrm{Co}_{3} \mathrm{O}_{4}$ and $\mathrm{LiCoO}_{2}{ }^{13}$.

Table II. Positions of XRD lines corresponding to phase 1 and 2 of lithium cobaltite.

\begin{tabular}{|c|c|c|c|}
\hline $\mathrm{N}^{\mathrm{o}}$ & $2 \theta$ & h k 1 & Phase \\
\hline 1 & 19.0470 & $\begin{array}{lll}1 & 1 & 1\end{array}$ & 2 \\
\hline 2 & 19.1680 & $\begin{array}{lll}1 & 1 & 1\end{array}$ & 1 \\
\hline 3 & 31.3510 & 220 & 2 \\
\hline 4 & 31.5520 & 220 & 1 \\
\hline 5 & 36.9410 & $\begin{array}{lll}3 & 1 & 1 \\
\end{array}$ & 2 \\
\hline 6 & 37.1810 & $\begin{array}{lll}3 & 1 & 1\end{array}$ & 1 \\
\hline 7 & 38.6480 & 222 & 2 \\
\hline 8 & 38.9000 & 222 & 1 \\
\hline 9 & 44.9270 & 400 & 2 \\
\hline 10 & 45.2250 & 400 & 1 \\
\hline 11 & 49.2130 & 3331 & 2 \\
\hline 12 & 49.5420 & 331 & 1 \\
\hline 13 & 55.8060 & 422 & 2 \\
\hline 14 & 56.1860 & 422 & 1 \\
\hline 15 & 59.5190 & 333 & 2 \\
\hline 16 & 59.5190 & $\begin{array}{lll}5 & 1 & 1 \\
\end{array}$ & 2 \\
\hline 17 & 59.9300 & 333 & 1 \\
\hline 18 & 59.9300 & $\begin{array}{lll}5 & 1 & 1 \\
\end{array}$ & 1 \\
\hline 19 & 65.4180 & 440 & 2 \\
\hline 20 & 65.8800 & 440 & 1 \\
\hline 21 & 68.8230 & $\begin{array}{lll}5 & 3 & 1 \\
\end{array}$ & 2 \\
\hline 22 & 69.3160 & $\begin{array}{lll}5 & 3 & 1\end{array}$ & 1 \\
\hline 23 & 69.9400 & 442 & 2 \\
\hline 24 & 70.4430 & 442 & 1 \\
\hline 25 & 74.3360 & 620 & 2 \\
\hline 26 & 74.8810 & 620 & 1 \\
\hline 27 & 77.5700 & $\begin{array}{lll}53 & 3 \\
\end{array}$ & 2 \\
\hline 28 & 78.1480 & 533 & 1 \\
\hline 29 & 78.6380 & 622 & 2 \\
\hline 30 & 79.2280 & 622 & 1 \\
\hline 31 & 82.8770 & 444 & 2 \\
\hline 32 & 83.5130 & 444 & 1 \\
\hline 33 & 86.0290 & $\begin{array}{lll}5 & 5 & 1 \\
\end{array}$ & 2 \\
\hline 34 & 86.0290 & $\begin{array}{lll}7 & 1 & 1 \\
\end{array}$ & 2 \\
\hline 35 & 86.7010 & $\begin{array}{lll}5 & 5 & 1 \\
\end{array}$ & 1 \\
\hline 36 & 86.7010 & $\begin{array}{lll}7 & 1 & 1\end{array}$ & 1 \\
\hline 37 & 91.2600 & 642 & 2 \\
\hline 38 & 91.9970 & 642 & 1 \\
\hline
\end{tabular}

Electrochemical measurements.

The lithium insertion/extraction process, using the Li-Co oxide, was studied. Figure 3 shows the discharge curve corresponding to the insertion of additional lithium ions into the spinel $\mathrm{Li}_{1+\mathrm{x}} \mathrm{Co}_{2} \mathrm{O}_{4}$ using $78 \mu \mathrm{Acm}^{-2}$ as current density and open-circuit voltage (OCV) curve. After the voltage drop, corresponding to $\mathrm{x}=0.02$, the CCV profile shows a plateau over the $2.1-2.4 \mathrm{~V}$ range which corresponds to the insertion of $\mathrm{Li}^{+}$ions into empty $16 \mathrm{c}$ octahedral sites. Note the gap $(\sim 1 \mathrm{~V})$ between OCV and CCV curves. 


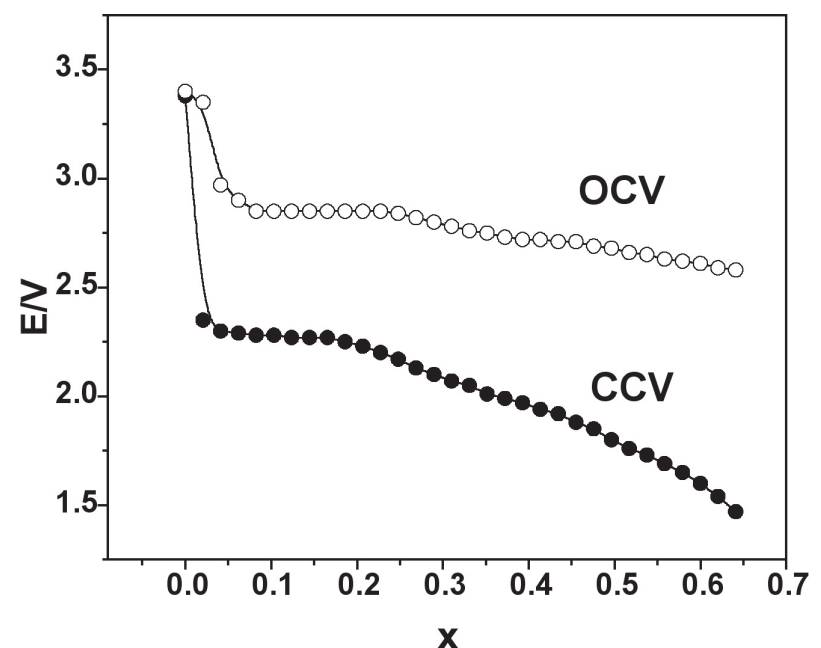

Figure 3. Lithium insertion curves at $\mathrm{j}=78 \mu \mathrm{A} \mathrm{cm} \mathrm{cm}^{-2}(\mathrm{CCV}$, closed symbols) and OCV (open symbols).

Li-Co spinel samples were first discharged to give $\mathrm{Li}_{1+} \mathrm{Co}_{2} \mathrm{O}_{4} \quad 1 \leq(1+\mathrm{x})$ $\leq 1.65$ and then subjected to a lithium extraction (Fig. 4). A large separation

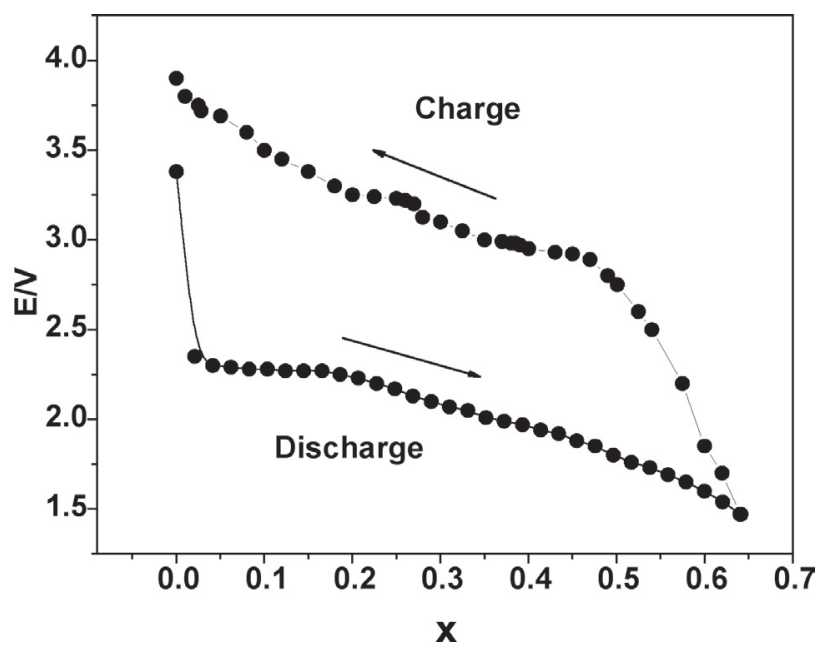

Figure 4. Discharge-charge curves for lithium cobaltite.

between discharge and charge profiles suggest an important polarization loss. During the charge process OCV profiles were placed between 2.8 and 3.7 $\mathrm{V}$ (not shown), similar to the OCV profile shown in Fig. 3, suggesting good reversibility. Previous reports have described the conservation of the $\mathrm{Li}_{1-x} \mathrm{Co}_{2} \mathrm{O}_{4}$ spinel framework during the insertion/extraction process ${ }^{12}$. Lithium insertion into the 16c sites occurs around 2.1-2.4 V, whereas lithium extraction from $8 \mathrm{a}$ sites occurs at 3.2-3.8V regarding oxide electrode values (Fig. 4), which do not match theoretical calculations ${ }^{19}$.

Lithium ion diffusion coefficient $\mathrm{D}$ was determined from the impedance spectrum-(Fig. 5). For a simple insertion electrode reaction, with either charge

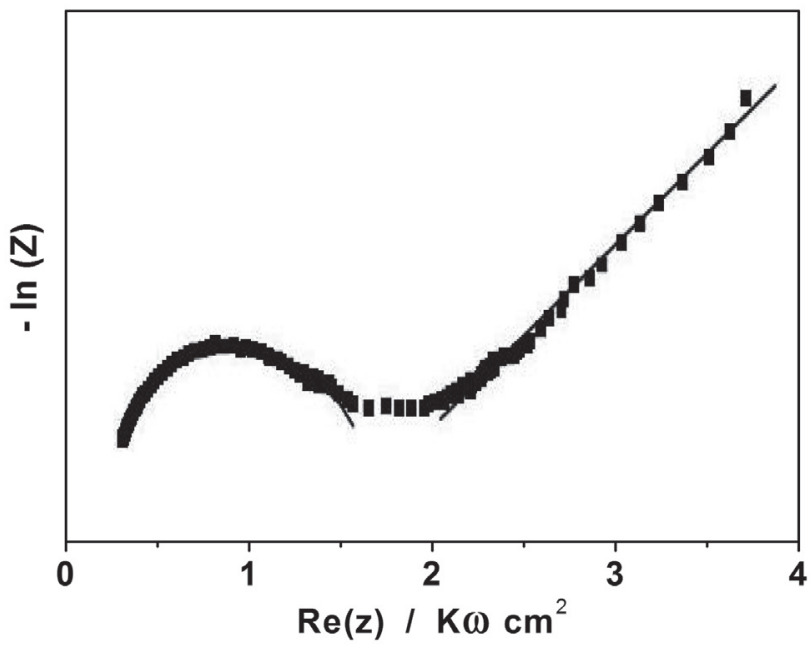

Figure 5. Impedance spectrum for lithium-cobalt oxide.

transfer or diffusion controlled kinetics; the equivalent circuit is a series combination of the charge transfer resistance $\mathrm{R}$, and the Warburg diffusion impedance $Z_{w}$, shunted by the double layer capacity $C_{d l}$. The diffusion process can be described by $Z_{w}=Z(1-j) \omega^{-1 / 2}$. The chemical diffusion coefficient $D$ is determined from the equation $|\mathrm{Z}|=\left[\mathrm{V}_{\mathrm{m}}(\mathrm{dE} / \mathrm{dx}) / \mathrm{nFaD}^{1 / 2}\right] \omega^{-1 / 2}$ where $\mathrm{V}_{\mathrm{m}}$ is the molar volume of the oxide, $\mathrm{dE} / \mathrm{dx}$ is the slope of the insertion curve $\mathrm{e}^{20}$ in the 2.1$2.4 \mathrm{~V}$ potential range. Impedance curves showing a well defined response with a semicircle at high frequency are seen, which are related with $\mathrm{R}_{\mathrm{ct}}$ in the oxide/ electrolyte interface and with the Warburg line at low frequency corresponding to the diffusion of lithium ion into the oxide. A D value of $8 \times 10^{-16} \mathrm{~cm} \mathrm{~s}^{-1}$ was obtained, which is low as compared with that of cobaltite obtained by SolGel (SG) methods $\left(D=610^{-15} \mathrm{~cm} \mathrm{~s}^{-1}\right)^{21}$. Moreover, the observed insertional behavior does not match with the oxide a-cell parameter, where $\mathrm{a}_{\mathrm{TDN}}>\mathrm{a}_{\mathrm{SG}}$. The low D observed could be accounted for the interstitial presence of $\mathrm{Co}$ in the TDN oxide ${ }^{21}$.

\section{CONCLUSIONS}

A lithium cobaltite oxide was synthesized using the conventional TDN method. A mixture of two phases $\left(66 \%\right.$ of $\mathrm{LiCo}_{2} \mathrm{O}_{4}$ and $34 \%$ of $\left.\mathrm{Co}_{3} \mathrm{O}_{4}\right)$ was obtained, both crystallized in the $\mathrm{Fd} 3 \mathrm{~m}$ space group.

The discharge process, corresponding to $\mathrm{Li}^{+}$insertion into empty $16 \mathrm{c}$ octahedral sites and the charge process, corresponding to lithium extraction from 8a sites, occurred at 2.1-2.4 V and 3.2-3.8 V potential ranges, respectively.

EIS measurements identified a lithium diffusion process in the oxide matrix with a $\mathrm{D}=810^{-16} \mathrm{~cm} \mathrm{~s}^{-1}$.

Electrochemical activity of this oxide mix was similar to that of $\mathrm{LiCo}_{2} \mathrm{O}_{4}$ (spinel like) prepared from $\mathrm{LiCoO}_{2}$ by chemical oxidation ${ }^{12}$.

\section{ACKNOWLEDGEMENTS}

This work received financial support from CONICYT (Fondecyt $\mathrm{N}^{\circ}$ 1050178 grant)

\section{REFERENCES}

1. J. Kim, P. Fulmer, A. Manthiram, Mat. Res. Bull. 34, 571, (1999)

2. B. Garcia, J. Farcy, J.P. Pereira-Ramos, N. Baffier, J. Perichon, J.Power Sources 54, 373, (1995)

3. S.G. Kang, Y.S. Kang, K.S. Ryu, S.H. Chang, Solid State Ionics 120, 155 , (1999)

4. D. Larcher, M.R. Palacín, G.G. Amatucci, J.M. Tarascon, J.Electrochem. Soc. 144, 408, (1997)

5. S.K. Chang, H.J. Kweon, B.K. Kim, D.Y.Jung, Y.U. Kwon, J.Power Sources 104, 125, (2002)

6. G.G.Amatucci, J.M.Tarascon, D. Larcher, L.C. Klein, Solid State Ionics 84, 169, (1996)

7. T.Watanabe, H. Uono, S.W. Song, K.S. Han, M.Yoshimura, J.Solid State Chem. 162, 364, (2001) 
8. J.H. Lee, K.S. Han, B.J. Lee, S.I. Seo, M.Yoshimura, Electrochim. Acta 50, 467, (2004)

9. H. Wang, Y. Jang, B. Huang, D.R. Sadoway, Y.M. Chiang, J.Electrochem Soc. 146, 473, (1999)

10. P.G. Bruce, A.R. Armstrong, R.L. Gitzendanner, J.Mater Chem. 9, 193, (1999)

11. R.J. Gummow, D.C. Liles, M.M. Thackeray, Mat.Res.Bull. 28, 235, (1993)

12. S. Choi and A. Manthiram, J.Electrochemical.Soc. 149, A162, (2002)

13. C. Wolventon and A Zunger, J.Electrochem.Soc. 145, 2424, (1998)

14. S. Choi and A. Manthiram, J.Solid State Chem. 164, 332, (2002)
15. JCPDS-International Centre for Diffraction Data. PCPDFWIN, V. 2.4, 2003

16. E. Antolini, Solid State Ionics 170, 159, (2004)

17. J. Rodríguez-Carvajal Fullprof 2000 Program, version 2001, July 2001, LLB JRC.

18. E.Ríos, G.Zelada, J.F.Marco and J.L.Gautier. This Journal 43, 447, (1998)

19. A.Van der Ven and G. Ceder, Phys.Rev.B. 59, 742, (1999)

20. E. Gileadi, Electrode Kinetics, VCH Publishers Inc. 1993 p.p. 476

21. E. Meza, PhD Thesis, U. Santiago Chile- U.L.P. Strasbourg, 2002 